\title{
The Right to be Publicly Naked: A Defence of Nudism
}

\section{Bouke de Vries ${ }^{1}$}

Published online: 18 September 2018

(C) The Author(s) 2018

\begin{abstract}
Many liberal democracies have legal restrictions on nudism. This article argues that when public nudity does not pose a health threat (which it seldom does), such restrictions are unjust. To vindicate this claim, I start by showing that there are two weighty interests served by the freedom to be naked in public. First, it promotes individual well-being; not only can nudist activities have great recreational value, recent studies have found that exposure to non-idealised naked bodies has a positive impact on body image, and, ultimately, on life satisfaction. Second, public nudity has expressive value; apart from being a constitutive element of various spiritual and religious worldviews, public nudity is frequently used to protest (perceived) social and political evils. As I go on to argue, the reasons for abolishing current antinudist laws that stem from these interests are not overridden, let alone cancelled, by the offence that public nudity might cause. Indeed, whereas my principal aim is to defend the freedom to be publicly naked when this poses no health threat, I will contend that states should recognise this liberty as a distinct legal right rather than try to subsume it under existing rights or secure it simply by excluding non-sexual, non-exhibitionist public nudity from existing laws against public indecency, sexual exhibition, and disorderly conduct.
\end{abstract}

Keywords Nudism · Naturism $\cdot$ Public nudity $\cdot$ Body image $\cdot$ Offence $\cdot$ Freedom of expression

\section{Introduction}

While liberal democracies often pride themselves on their liberties, many have farreaching restrictions on nudism. There are various offences under which nudism or public nudity (I will use these terms interchangeably) might be circumscribed within these societies. These include, but are not limited to: indecent exposure, public

Bouke de Vries

devries@mmg.mpg.de

1 Department of Ethics, Law, and Politics, Max Planck Institute for the Study of Religious and Ethnic Diversity, Herman-Föge-Weg 11, 37073 Göttingen, Germany 
indecency, sexual exhibition, disturbances to public order, and threats to public peace (Hörnle 2006). In France, for instance, the penal code proscribes "Publicly visible sexual exhibition in public zones", an offence that is punishable by 1 year of imprisonment and a 15,000 euro fine. ${ }^{1}$ In the UK, the Public Order Act of 1986 proscribes public nudity when it is likely to cause "harassment, alarm or distress" 2 (though nudists are frequently arrested even when it is doubtful whether this conditional is met; more on this below). In the Netherlands, article 430a of the civil code proscribes public nudity when it is "evidently not suitable", ${ }^{3}$ but does not specify when this is the case. In the US, approaches towards nudism can differ markedly among its states, as a comparison between Oregon and Arkansas illustrates. Whereas Oregon legally protects public nudity as free speech, provided there is no "intent to arouse", 4 Arkansas not only proscribes nudism beyond the immediate family unit (including nudity on private property), but also criminalises the promotion and advocacy of pro-nudist views, which is punishable by a $\$ 2500$ fine and up to a year in jail. ${ }^{5}$

These and other anti-nudist laws and ordinances have not been toothless. In 2014, a group of Dutch naturists received 90-euro fines for naked recreation in a park where they had been gathering for over 30 years. ${ }^{6}$ Previously, the municipality had banned public nudity from the park, arguing that naked recreation had become unsuitable due to increased visitor numbers and the risk that the presence of nudist recreants may deter restaurants and cafes from settling in the area. ${ }^{7}$ In fact, for public nudity to be merely visible from public areas can already trigger sanctions under Dutch law. In 2009, a 55-year old man from Amersfoort was fined for walking naked in his own home (without closing the curtains) after he had been warned twice by local authorities to dress up. ${ }^{8}$ In the UK, nudists have suffered even harsher penalties. Consider the case of Stephen Gough, a war veteran who has become known for his naked hikes through the UK, which have given him the nickname of the 'Naked Rambler'. After being repeatedly charged with breaching anti-social behaviour orders, Gough has spent about 10 years of his life behind bars (part of which in solitary confinement for refusing to wear clothes in prison ${ }^{9}$ ), causing him to miss much of his children's childhoods. Likewise, Terri Sue Webb, a pro-nudism activist, has been imprisoned multiple times for public nudity within the

\footnotetext{
${ }^{1} \mathrm{http}: / / \mathrm{www}$.naturismedroit.net/component/content/article?id=1.

2 http://www.cps.gov.uk/legal/1_to_o/nudity_in_public/.

3 http://www.artikel430a.nl/naaktrecreant.html.

${ }^{4}$ http://naturistaction.org/StatesFrames/State_Laws_Frames/Oregon_Laws/body_oregon_laws.html.

5 https://www.arktimes.com/arkansas/group-wants-arkansass-prude-nude-law-revoked/Content?oid= 4345924.

${ }^{6}$ https://nos.nl/artikel/603323-nudist-op-druk-strand-alsnog-beboet.html.

7 https://nos.nl/artikel/603323-nudist-op-druk-strand-alsnog-beboet.html.

${ }^{8}$ https://www.demorgen.be/buitenland/nederlander-op-de-bon-voor-naaktlopen-in-eigen-huis-bd6dddad/.

9 http://www.independent.co.uk/news/uk/home-news/naked-rambler-stephen-gough-walks-free-andnaked-7953497.html.
} 
US. On several occasions, her refusal to wear clothes in prison has resulted in longer jail sentences. ${ }^{10}$

It would be mistaken to see these laws and ordinances as relics of Victorian sensibilities that will sooner or later be replaced by a more liberal approach towards the naked body. The untenability of such a Whiggish view of ever-expanding freedom is illustrated by recent developments in Spain and California. While Spain has traditionally been tolerant of nudism, its Supreme Court authorised local authorities to restrict public nudity in 2009. Despite protests by nudist organisations, various municipalities have subsequently restricted nudism on public beaches (e.g. Castell-Platja d'Aro, Cádiz, Valladolid), reportedly with the aim of appeasing visiting families. ${ }^{11}$ Similarly, San Francisco (of all places) decided to ban public nudity in 2012. ${ }^{12}$ Whereas first-time violations of this ban are subject to a 100-dollar fine, second citations cost 200 dollars and third-time offences result in a fine up to 500 dollars and a prison sentence of up to 1 year. ${ }^{13}$

In short, not only is true that contemporary liberal democracies heavily circumscribe public nudity, there is little reason for believing that these restrictions are bound to be lifted eventually. As the Spanish and San Franciscan cases evince, anti-nudist laws can become more stringent, which fits into a broader pattern of expanding nuisance and offence-related legislation across liberal societies (Persak 2016).

The aim of this article is to show that the above (and comparable) restrictions on nudism are unjust. It argues that when public nudity poses no health threat-as it rarely does-states should allow it. Specifically, my contention is that states should recognise this liberty as a distinct right rather than try to protect it under existing rights, or secure it simply by excluding non-sexual, non-exhibitionist public nudity from existing laws against public indecency, sexual exhibition, and disorderly conduct. By a 'right to be publicly naked', I mean a legally protected liberty to be naked in a range of places, including public beaches, streets, squares, and forests. For present purposes, I will not focus on privately-owned spaces to which members of the general public have entry, such as swimming pools and shopping malls. While I believe there is a case for requiring owners of such places to admit nude visitors, defending this claim is beyond this paper's remit.

\section{Reasons for Recognising a Right to be Publicly Naked}

To defend a right to engage in some action, or to refrain from doing so, I take it that it is necessary to identify interests in the relevant (in)action that are strong enough to merit legal protection ( $\operatorname{Raz}$ 1988). Accordingly, to defend a right to be publicly naked, we must identify the interests served by such a right.

\footnotetext{
${ }^{10} \mathrm{http} / / /$ naturistaction.org/Local_Issues/Bend__Oregon/bend_oregon.html.

11 https://elpais.com/elpais/2016/06/22/inenglish/1466605165_976373.html.

12 http://www.nytimes.com/2012/11/21/us/san-francisco-officials-vote-to-ban-public-nudity.html.

13 https://www.theatlantic.com/national/archive/2012/11/san-franciscos-naked-days-are-over/321263/.
} 


\section{Well-Being}

One such interest lies in its potential contributions to people's well-being. As we will see below, not only can a right to be publicly naked promote the well-being of many nudists, but also those of many non-nudists whose body image and, ultimately, life satisfaction, might be promoted by exposure to non-idealised naked bodies (i.e. bodies that fall short of prevailing aesthetic standards). To show that the freedom to be naked in public can make significant (morally innocent) contributions to well-being, I will adduce three kinds of evidence: testimonial, abductive, and empirical.

\section{Testimonial Evidence}

Whereas nudists are often depicted as sexual miscreants or psychologically disturbed individuals, there are abundant testimonies that practising nudism can bring pleasures that are neither immoral nor pathological. For example, a journalist of the Guardian described his first naked hike as follows:

Being naked is profoundly liberating. It's not just the physical feeling of the air, sun or sea over your entire body: there's a psychological release, too. When you shed your clothes, many social pressures also somehow fall away. ${ }^{14}$

Such experiences are by no means limited to first-time nudists. Andrew Welch, an experienced naturist and spokesperson of British Naturism, speaks of a

[...] a liberating feeling when you're naked in the fresh air, or skinny-dipping, or jumping in a hot tub. ${ }^{15}$

Or consider the testimony of Richard Collins, an electrical engineer and nudist of three decades who has become known for his naked bike rides through Cambridge, England (and subsequent arrests). When asked about his motivation for cycling nude, he replied:

Cycling is a great way to get a bit of exercise in itself - but especially without any clothes on [...] You feel the breeze on your skin, and the sun on your skin - it feels wonderful. ${ }^{16}$

Indeed, taking pleasure in nude recreation is not unique to our day and age. Recounting his trip to a naturist resort near Bremen (Germany) in the early 1930s, Howard Warren reported a

[...] distinct joy in the free movements of the naked body which is lacking when one is clothed in the conventional gym-suit (Warren 1933, p. 172).

\footnotetext{
14 https://www.theguardian.com/lifeandstyle/2017/jan/27/britain-undress-charlie-gilmour-naked.

15 https://www.theguardian.com/lifeandstyle/2017/jan/27/britain-undress-charlie-gilmour-naked.

16 http://www.bournemouthecho.co.uk/news/8252825.No butts as_nude_cyclist_is_arrested_ after_riding_through_Bournemouth_and_Poole/.
} 
As well as a

A peculiar joy in wandering naked through the cool pine woods, whether by day or by moonlight, which is far superior to airbathing in a restricted garden (Warren 1933, p. 172).

These and numerous other testimonies that I could have included-but have not for reasons of space-provide good evidence that nudism can make positive contributions to people's well-being. To avoid confusion, I am not suggesting that being naked in public (or in private for that matter) is invariably pleasurable for those who engage in it. ${ }^{17}$ There are many situations in which it might not be, for example when the weather is cold or when being unclothed would expose oneself to insect bites. However, defending a right to be publicly naked does not require one to show that that being publicly naked is always pleasurable. It merely needs to be shown that there are at least some occasions where it brings net pleasure to people. Since there is no reason for believing that all of the above testimonies - and various other ones that could have been provided-are inaccurate, such occasions appear to exist.

\section{Abductive Evidence}

The abovementioned tastes for nude recreation are by no means idiosyncratic. Polls conducted by Ipsos-Mori suggest that about a quarter of all Britons have taken part in some nudist activity between 2001 and 2011, such as nude sunbathing. ${ }^{18}$ In the Netherlands, the national naturist organisation (NFN) boasts approximately 72,000 members, ${ }^{19}$ whereas approximately 600,000 individuals are registered with private nudist or Freikörperkultur [free body culture] clubs in Germany. More recently, naked bike rides have garnered widespread public interest; cities such as Portland, Amsterdam, and Mexico-City (among many others) participate in the annual World Naked Bike Ride, with the 2017 Portland edition alone attracting nearly 9000 participants. ${ }^{20}$ Such figures complement the abovementioned testimonial evidence by providing abductive evidence of nudism's potential to promote individual wellbeing. The idea is that unless nudism has this potential, it becomes difficult to explain why so many individuals practice it and why some are even willing to do so at the risk of incurring legal and/or social sanctions. Lending further support to this inference is the fact that nude recreation is not unique to our age. While the German Freikörperkultur dates back to the nineteenth century, some of the earliest examples of nudist activities - and societal acceptance thereof - can already be found in Ancient Athens, whose male citizens practiced nude athletics (Górnicka 2016).

To be sure, I am not claiming that everyone who practices nudism will experience net pleasure (or that everyone who does so practices nudism in order to experience pleasure, or that pleasure is all that matters as some utilitarians maintain). There can be, and undoubtedly are individuals for whom being publicly

\footnotetext{
17 I am indebted to one of the reviewers for pressing me on this.

18 http://www.bn.org.uk/news/news/nearly-4-million-naturists-in-the-uk-r97/.

19 https://www.rtlnieuws.nl/editienl/rondlopen-je-nakie-moet-kunnen.

20 https://pdxwnbr.org/.
} 
naked does not have these effects. All that I am claiming is that it is unlikely that nudism would be such a popular and persistent phenomenon if it did not promote the well-being of certain groups of nudists.

A Counterproductivity Objection At this point, we should ponder the possibility that any well-being-promoting effects of nudism depend on public nudity remaining largely banned. The thought here is this: If the joy of nudism depends on the feelings of liberation that it induces-recall, for instance, the BBC journalist who reported a "psychological release" when wandering through town naked-and if the existence of such feelings depends on nudism remaining largely proscribed (unless some action is prohibited or taboo in some way or other, it is difficult to see how doing that action could be liberating), then by largely decriminalising it, nudism would cease to promote people's well-being.

An immediate reply is that even if this mechanism obtains, the idea that coercive laws should be left in place for the joy of breaking them is a reductio ad absurdum. Though I am sympathetic to this view, it should be noted that even if it is not a reductio, this would still not justify the scope of existing restrictions on public nudity. To vindicate this claim, we need to consider the well-being-related costs of maintaining such restrictions.

These costs include diminished access to the well-being promoting effects of nudism that do not depend on the sustenance of anti-nudist laws. For examples of such effects, one might recall Collins' description of the "wonderful" feeling of the breeze and sun on your skin, or Warren's report of the delight in the "free movements of the naked body which is lacking when one is clothed in the conventional gym-suit". Being akin to basic physical sensations, the pleasure of these experiences is not reduced by the legalisation of nudist activities. (Likewise, we will see below that exposure to non-idealised naked bodies can have a positive impact on body image, and, ultimately, on life satisfaction, that is not diminished by the decriminalisation of public nudity.)

Besides denying opportunities for enhanced well-being to people, sustaining antinudist laws can adversely affect their current well-being. Such reductions in wellbeing might be caused by the penalties on violating anti-nudist laws (e.g. fines, prison sentences); the fear that nudists might have of being caught violating such laws; the feelings of guilt that such violations might induce in them; and-when anti-nudist laws are vague-the uncertainty that they might suffer about whether they are acting illegally by appearing naked in certain places. The following remark by Mark Nisbet, editor of Health \& Efficiency Magazine, captures many of these evils:

The moral and legal climate in the UK is very harsh when it comes to public nudity. It encourages apprehension and fear among those nudists who are less bold than the very small minority of nudists with an attitude, who go nude wherever they chose. ${ }^{21}$

21 https://www.theguardian.com/theguardian/2000/jun/09/debate. 
Further reductions in well-being might be engendered by ways in which nudists are stigmatised by proscriptions on nudism. Such stigmatisation occurs, for instance, when these individuals are persecuted under (sexual) misconduct laws and when they are forced to gather on designated places (e.g. nudist beaches). Not only are these things degrading, they are also widely experienced as such; as Nisbet points out, many nudists are "vexed by segregation and angered at being one notch up from sexual exhibitionists in the eyes of the law". ${ }^{22}$ Or consider the following statement by Joaquim Plana, president of the Catalan Naturist Club, on a recently introduced nudity ban on a Catalan beach:

What bothers us is that they include us in the civic ordinance, describing our behaviour as antisocial. There's nothing further from reality [...] They say it's to protect families, but we also have families. Nudists aren't odd people. ${ }^{23}$

What these observations suggest is that even if the notion that the joy of breaching certain laws can be a reason for maintaining those laws is not a reductio-as I believe it is - the pleasure that nudists may derive from breaching current antinudist laws will usually be outweighed by the disutility that maintaining such laws engenders. Furthermore, once we add to the equation people's expressive interests in their abolishment (which are discussed shortly), the sustenance of current largescale restrictions on public nudity becomes even more difficult to defend.

\section{Empirical Evidence}

A third source of support for the link between nudism and well-being is provided by empirical studies of the last few decades (e.g. Lewis and Janda 1988; Okami et al. 1998; Okami 1995; Oleinick et al. 1966; West 2017). Besides showing that exposure to (non-exhibitionist) public nudity lacks the detrimental psychological and behavioural effects commonly attributed to it, these studies have found that such exposure can have positive effects on well-being by promoting people's body image.

Consider these findings in the order stated. Whereas it is often feared that exposure to nudity has a detrimental psychological and behavioural impact on children, this has not been corroborated by empirical research. Studies by Oleinick et al. (1966) and Lewis and Janda (1988) found no relationship between early-life exposure to nudity and the development of psychiatric symptoms later in life. In an 18-year longitudinal outcome study, Okami et al. (1998) assessed the relationship between early-life exposure to parental nudity and levels of self-acceptance; relations with peers, parents, and other adults; antisocial and criminal behaviour; substance use; suicidal ideation; quality of sexual relationships; and problems associated with sexual relations. No adverse effects were found. In fact, some positive effects were reported for boys and/or women, including reduced risk of teenage pregnancy; contracting sexually transmitted diseases; use of recreational

\footnotetext{
22 https://www.theguardian.com/theguardian/2000/jun/09/debate.

23 https://www.theguardian.com/world/2015/apr/23/catalan-naturist-club-nudists-castell-platjadarostrasbourg.
} 
drugs; antisocial behaviour; and higher levels of self-acceptance (Okami et al. 1998).

More recent studies have linked exposure to non-idealised nude bodies-i.e. bodies that do not meet the standards of thinness for women and muscularity for men that are commonly depicted in the media and advertisement-to improved body image (Swami 2016; West 2017). These findings are pertinent, as improved body image has been shown to promote life satisfaction through its positive impact on self-esteem (Acun-Kapikiran et al. 2014; Kostanski and Gullone 1998; Olivardia et al. 2004; Paradise and Kernis 2002; Park et al. 2014; Pujols et al. 2010). Whereas Swami (2016) found that women who regularly participated in drawing sessions that featured live (naked) models had higher body appreciation, as well as a lower drive for thinness and lower social physique anxiety, West (2017) found that participation in naturist activities tends to conduce to a more positive image of one's own body (whereby seeing others naked was found to be to be more important than being seen naked by others).

So far, I have marshalled testimonial, abductive, and empirical evidence for the claim that a right to be publicly naked can make significant contributions to wellbeing. To make a conclusive case for such a right, however, we must address the objection that many individuals find public nudity offensive, and have their wellbeing undermined by it. Section 3 will examine the normative implications of such offence; for now, I want to look at another kind of interest that is served by a right to be publicly naked.

\section{Freedom of Expression}

Freedom of expression is frequently invoked in court cases over public nudity. For example, Stephen Gough appealed to it when he went to European Court of Human Rights over his repeated arrests and convictions for nude hiking, ${ }^{24}$ so did a group of nudists who filed a federal lawsuit against San Francisco's public nudity ban. ${ }^{25}$ Such appeals should not be surprising; apart from their usefulness as a litigative strategy, nudists and non-nudists often have strong expressive interests in the liberty to be publicly naked. Let me mention two.

One expressive interest is identity-related. For many nudists, the ability to appear naked in public is necessary for expressing their identity, and in so doing, maintaining a sense of personal integrity or wholeness. One might think of ecological groups who see naturism as a way of connecting "to mother nature, earth, trees, and water". ${ }^{26}$ Or consider God's Garden, a Christian nudist group in Florida whose members describes their congregation as

A celebration of life with like-minded people while furthering our understanding of the Creator. We understand that being clothes-free is not sinful; it is how we are designed by God to live. In this way, we are a welcome

\footnotetext{
${ }^{24}$ http://www.bbc.co.uk/news/uk-england-29800016.

25 https://www.mercurynews.com/2013/01/29/san-francisco-nudity-ban-upheld-in-federal-court/.

26 https://www.youtube.com/watch?v=7GcOPOdQ7S4.
} 
alternative to established Christian denominations which do not accept our chosen lifestyle. $^{27}$

For these and many other nudists, living under anti-nudist laws denies them the legal liberty to align their outer appearances with their inner convictions. Furthermore, even if they remain physically free to appear naked in public (only a straitjacket would deny them this liberty), doing so might mean that they will face fines and, ultimately, imprisonment, which can make it extremely costly to live in accordance with their nudist convictions.

The pressure that this imposes on nudists to desist from acting upon their deeply held beliefs is problematic for two reasons. First, insofar as they yield to such pressure, this will result in misalignments between their forum internum and externum that are detrimental to their well-being. Second, nudists' dignity is undermined by such pressure, as treating autonomous beings in dignified ways requires that they be left free to act upon their conceptions of the good life when this does not impose unreasonable costs on others (having already debunked various myths about nudism's pernicious effects, Sect. 3 will say more in defence of the notion that the costs of allowing public nudity are not unreasonable).

The other expressive interest in the freedom to be publicly naked is communicative. While the ability to express our identity-constituting commitments can matter independent from whether others recognise our identities, such recognition can be pertinent as well. Apart from any positive value that it might have, misrecognition by others can, and often does, lead to serious harms, including distorted relations-to-self, such as low self-esteem and even self-hatred (Laitinen 2012). For example, for people with fluid genders to be recognised by others as either male or female can have a detrimental impact on their self-esteem. Similarly, for nudists to be seen as individuals who believe in the sinfulness or indecency of the naked body can dent their sense of their own worth. If correct, then just as forcing those with fluid genders to identify as male or female is problematic because it conduces to such misrecognition, so forcing nudists to wear clothes is at least pro tanto objectionable, as it makes it more likely that their identities will be misrecognised.

Another way in which anti-nudism legislation might undermine communicative interests is by inhibiting both nudists and non-nudists from using public nudity as a means of promoting their moral and political views. For examples of such usage, think of how nudity has been deployed to protest nuclear weapons, with slogans such as "Disrobe for Disarmament" 28 and "Nudes, not Nukes" ${ }^{29}$; or how it has been used to demonstrate against the fur industry with the slogan "I'd rather go naked than wear fur" ${ }^{30}$; or of how it has been used by the Ukrainian group FEMEN to demonstrate against sex tourism, international marriage agencies, and violence against women. ${ }^{31}$ Besides being used for the promotion of non-nudist causes, public

\footnotetext{
27 https://www.meetup.com/Gods-Garden-for-Naturist-Christians/?_cookie-check= JxGjwut4xNXwoGYx.

${ }^{28}$ https://de.indymedia.org/2003/02/41058.shtml.

29 http://www.washingtonpost.com/wp-srv/aponline/19991004/aponline172802_000.htm.

30 https://www.huffingtonpost.com/2009/03/23/id-rather-go-naked-than-w_n_177920.html.

31 https://femen.org/.
} 
nudity is often used for promoting the nudist agenda itself, in which case public nudity is both an expression of an identity and a means for furthering certain political ends. Examples of this can be found in the (partially) naked protests that have been staged against restrictions on breast-feeding, ${ }^{32}$ female toplessness, ${ }^{33}$ and full-blown nakedness. ${ }^{34}$

While protests can be successful without the use of nudity, naked protests are often highly effective in attracting public attention. Indeed, they might sometimes even be the only effective means. For example, the fact that women's voices are routinely ignored within patriarchal societies suggests that FEMEN may be right in claiming that their campaigns would "not be noticed" if they used "banners" rather than nudity. ${ }^{35}$

\section{A Counterproductivity Objection}

Some might respond that even if public nudity is a highly effective and efficient means of protest for some groups, its usefulness as a vehicle of protest is not be served by decriminalising it. The thought is that if what makes naked protests so successful - as measured by the amount of public attention that they receive-is that the protestors are willing to breach anti-nudist laws to promote their causes, then by decriminalising public nudity, the potency of those messages-and subsequent public interest-will be weakened by lowering the costs of naked protests.

One immediate rejoinder is that even when abolishing anti-nudist laws reduces the effectiveness of such protests, this does not adversely affect those who use public nudity to advocate nudist causes. This is because the abolishment of antinudist laws is exactly what these individuals are trying to achieve. However, this would still allow for the possibility that decriminalising public nudity will adversely affect those who employ public nudity to further non-nudist causes, as the abolishment of anti-nudist laws is not part of their agenda.

What should we make of this objection? While any reduced efficiency of nudism as a tool for furthering non-nudist causes might be regrettable, I believe it does not justify the sustenance of current anti-nudist laws. Even if naked protests lose (some of) their force, the present objection is softened considerably by the fact that various alternative - and potentially at least as effective-ways of attracting public attention will usually remain available to people, including to marginalised groups. One might think of staging sit-ins, holding of marches, and refusing to stand up for the national anthem (a form of protest currently used in the US to protest police brutality against black individuals). Furthermore, given human propensities for creativity and innovation, people are bound to come up with new forms of protesting.

\footnotetext{
32 http://www.bbc.co.uk/news/uk-england-london-30359606.

${ }^{33}$ See, for instance, the protests of the Topfree Equal Rights Association (TERA) in Canada: http://www. tera.ca/.

34 https://www.theguardian.com/us-news/2015/feb/02/nude-protesters-arrested-isan-francisco-nudityban.

${ }^{35}$ http://www.the-platform.org.uk/2013/06/27/the-femen-and-a-womens-spring/.
} 
When we consider the existence of these (potential) alternative forms of protest along with the strong well-being related and expressive interests in the freedom to be publicly naked as outlined in this section and the previous one, it seems that any reduction in the efficiency of nude protests that might ensue from the abolishment of current anti-nudist laws is a price worth paying.

\section{The Case for a Distinct Right}

The foregoing subsections have argued that there are weighty interests served by the freedom to be naked in public. To make a conclusive case for (largely) decriminalising nudism, however, several concerns must be addressed. Before turning to these, we need to consider why-as I have suggested-states ought to recognise a distinct right to be publicly naked rather than subsume nudist liberties under existing rights, or simply secure them by excluding non-sexual, nonexhibitionist public nudity from existing laws against public indecency, sexual exhibition, and public disorder (an example of such a built-in exemption can be found in Oregon's indecent exposure laws, which allow for the-otherwise impermissible_-public display of genitals when there is no "intent of arousing [...] sexual desire" $)^{36}$. Consider these alternatives in the order stated.

The problem with subsuming the freedom to be publicly naked under traditional liberal rights is that such rights cannot capture all apposite interests in this liberty. To be sure, many important interests could be protected through this strategy; whereas the right to free expression could protect the identity-related and communicative interests in this freedom (see above), the right to conscientious freedom could protect nudist practices in which people feel conscientiously compelled to engage (think of the naked rituals of Christian naturalists and Wiccans). However, we have seen that many individuals engage in naked activities simply for the pleasure that this brings; in so doing, they are not trying to express, or live in accordance with, any spiritual, religious, or moral beliefs. For example, when asked about his motivations for cycling naked through Cambridge, Richard Collins replied that his outings are "simply me having fun!" 37 By introducing a distinct right to be publicly naked, states would not only recognise the interests of individuals with expressive or conscientious stakes in nudism, but also those of Collins and others who practice nudism for purely hedonistic reasons.

What about securing nudist liberties by simply excluding non-sexual, nonexhibitionist public nudity from existing laws against public indecency, sexual exhibition, and disorderly conduct?

This is not an adequate alternative either. For one thing, one might doubt whether building nudist exemptions into such laws puts the freedom to be publicly naked on a secure enough footing. Even if religious objections to nudism have become less common within liberal democracies due to processes of secularisation, this does not mean that prudishness is becoming extinct. Not only do many groups within these societies-religious and non-religious - continue to regard public nudity as indecent

\footnotetext{
${ }^{36} \mathrm{http} / / /$ statelaws.findlaw.com/oregon-law/oregon-indecent-exposure-laws.html.

37 https://www.purenudism.com/free/naked-skyscraper-event.html.
} 
(indeed, the Spanish and San Franciscan experiences show that Victorian sensibilities can be rekindled), the debunked notion that public nudity is bad for children continues to have a strong hold on large swathes of citizens. This is problematic, for it means that any nudist exemptions to laws against public indecency and sexual exhibition could be scrapped readily once a (more) prudish government and/or one with false beliefs about nudism's effects assumes power. While a right to be publicly naked could be revoked as well, once such a right is recognised, it will ordinarily be more difficult for future governments to criminalise nudism, not the least because of the symbolic status of rights as basic entitlements.

For another, the fact that rights have great symbolic value means that recognising a distinct right to be publicly naked is a more fitting way of redressing past injustices against nudists than merely exempting these individuals from antiindecency or anti-exhibitionist laws. As was mentioned, there are various ways in which anti-nudist laws have adversely affected nudists' interests (and continue to do so). Many have suffered legal penalties for their naked activities, whether in the forms of fines or imprisonment. Furthermore, those who have been spared this fate hitherto may still have feared such penalties, felt guilty about violating anti-nudist laws, and/or felt ashamed by the ways in which such laws stigmatise them. Indeed, regardless of whether anti-nudist laws have visited some disutility on them, nudists are harmed by such legislation, as the harm of stigmatisation does not require that those targeted suffer a reduction in their well-being (such reductions aggravate the relevant harm, but are not necessary for it). Those whose well-being is not diminished, perhaps because of their unawareness of the laws' stigmatising character or because of their stoic dispositions, still suffer a dignitary or status harm when they are stigmatised, which is an objective evil (a parallel might be drawn with the disenfranchisement of women in previous ages; even if some women did not bother about being denied the right to vote, their exclusion still visited a status or dignitary on them).

Of course, this all presupposes the injustice of existing (and past) anti-nudist laws. To show that these laws are in fact unjust, it is not only necessary to identify the interests served by the freedom to be publicly naked (as I have done in this section), but also to consider whether there are countervailing interests that act as defeaters for a right to this liberty. It is to this task that I turn next.

\section{Objections and Some Rejoinders}

\section{Hygiene}

One possible defeater is that public nudity poses significant risks to public health. To the extent that this is so, this would provide strong reason against the recognition of a right to be publicly naked, assuming that maintaining health- and safety standards is one of the state's key responsibilities.

However, such concerns seem overstated. For diseases to spread, it is a necessary-but by no means sufficient-condition that some form of direct or indirect contact takes place. Within most areas where nudism is commonly 
practiced, this condition does not obtain. Just by lying naked on the beach, or by wandering naked in the forest or through the countryside, nudists do not make contact with other individuals, whether directly or indirectly. The same applies when people cycle in their birthday suits or simply walk naked on the street.

Indirect contact does occur, of course, when nudists share a seat with others. Yet as health experts have pointed out, sharing seats with naked individuals exposes people only to very small quantities of pathogens, ones that can endured easily by a healthy immune system. ${ }^{38}$ Given the strong well-being related and expressive interests in nudism, such risks seem too small to justify current anti-nudist laws. What is more, insofar as these risks are deemed intolerable, we might need to ban shaking hands and the use of paper money and computer keyboards as well, given that these activities pose comparable risks. But this is surely a reductio.

Finally, even if we are squeamish about any additional bodily microbes spread by naked individuals, there will often be less restrictive means of neutralising the small risks these microbes pose than banning public nudity altogether. Most importantly, naked individuals could be required to bring an own towel to sit on, which is already required by many nudist- and naturist clubs. In addition, bans on nudity could be limited to crowed public spaces. ${ }^{39}$ For example, states might ban nudism on public subways or trains during peak commute hours only, which would still allow for naked travelling during off-peak hours (provided a towel is used). In short, while there is strong case for proscribing public nudity when it poses significant health risks, such cases seem rare and certainly do not justify the scope of existing restrictions on nudism.

\section{Offence}

A more serious objection to recognising a right to be publicly naked is that many people are offended by public nudity. 'Being offended' here means that for these individuals to witness naked bodies in the public domain induces some unpleasant mental state in them, which might involve disgust, shock, annoyance, anger, fear, and-when they feel ashamed on the nudist's behalf-embarrassment (Feinberg 1988 , p. 5). (Contrary to what is often thought, feelings of offence need not involve a blaming response; for example, people can be offended by a terrible stench "without holding anyone blameworthy or even responsible for causing the stench or failing to prevent or terminate it (Tasioulas 2006, p. 150). Similarly, I might be offended by the display of naked bodies even if I believe that the nudists in question are not to blame for their behaviour.)

Does nudism-induced offence justify the sustenance of current restrictions on nudism? To answer this question, we must know two things. One is whether people have good reasons for being offended, i.e. whether their offence is reasonable. This is necessary, as the degree of their offence cannot by itself determine whether state interference is due. Consider individuals who are offended by an interracial couple

\footnotetext{
38 http://www.slate.com/articles/news_and_politics/explainer/2011/09/does_public_nudity_spread_ disease.html.

39 As one of the reviewers pointed out to me.
} 
holding hands; no matter how extreme the offence experienced by these individuals is, its racist character renders it unsuitable as a ground for interfering with the couple's behaviour.

Besides asking whether feelings of offence are reasonable, or simply not unreasonable insofar as reasonableness is a trivalent notion, we must know whether state interference with those causing the offence would not be a greater evil than the offence they cause. For a case where this condition is not satisfied, one might think of the criminalisation of adultery. Even when people who are cheated on by their partners are rightly offended by the latter's infidelity, making adultery a criminal offence shows insufficient concern for people's freedom and privacy.

In what follows, I will argue that nudism-induced offence does not satisfy the criteria for criminalisation just specified.

\section{Ugly Bodies}

One reason why people might be offended by public nudity is that they find (certain kinds of) naked bodies ugly and, as a result, unpleasant to look at.

Even when such aesthetic offence is genuine, I believe it would be unreasonable to proscribe nudism on its basis. To see why, consider first cases where people find the naked bodies of some but not all members of their society ugly. Enacting laws to prevent such offence seems highly problematic, as it stigmatises those whose bodies are deemed ugly. These individuals would be made at least partially responsible for the fact that everyone within their society-with the possible exception of young minors - is legally required to wear clothing in public. To bring out the humiliation of this, it should be noted that a state that accepted such justifications for antinudism laws would be committing itself to the view that if the physiques of the relevant individuals had not been so ugly, or rather perceived to be ugly, there would have been no or fewer reasons to prevent people from going around naked. Even when the state abstained from assessing (and by implication affirming) the ugliness of these individuals' bodies itself, the fact that its justifications for antinudism laws included the judgements of private individuals that the relevant bodies are ugly seems degrading in and of itself.

Of course, when anti-nudism laws are justified on grounds that there are people who find the naked bodies of all members of their society ugly, the stigma of living under laws that are justified by perceptions of one's body as being uglier than those of other members of the society is absent. However, such laws would remain problematic, as they would still be justified by reference to perceptions that people's unclothed physiques are ugly, and, indeed, so ugly that they should cover up to avoid causing offence, which is degrading in a non-comparative sense. ${ }^{40}$

\footnotetext{
${ }^{40}$ In addition, some might worry that if aesthetic offence is treated as sufficient to justify existing antinudism laws, consistency might require that states proscribe various things that most of us would agree ought to be tolerated, such as wearing Crocs in public. Not only are Crocs found aesthetically displeasing by many, forcing people to refrain from wearing Crocs does not appear to be more intrusive than forcing individuals to cover up their private parts and chests.
} 


\section{Deviant Sexual Behaviour}

Another common reason why people might be offended by nudism is that they associate public nudity with base or immoral human behaviour, more specifically with deviant sexual acts. As was mentioned, nudists are often seen as exhibitionists, that is, as individuals who derive sexual gratification from exposing their genitals and/or breasts to strangers.

Such offence is unreasonable too, I believe, as it is based on highly misleading conceptions of nudists' motivations. By far most nudists engage in naked activities for the sake of their recreational, spiritual, and/or religious value rather than to gratify any sexual needs (indeed, it was noted that most of them are quite resentful for being perceived as exhibitionists).

This is not to deny that exhibitionism and other forms of sexually deviant behaviour, such as public masturbation, occur. They do, and such behaviours are rightly proscribed. However, this can be done without maintaining current antinudist laws, namely by selectively banning the relevant behaviours. Such surgical bans are superior, as they leave intact people's freedom to engage in morally innocent naked activities.

In response, some might argue that nudism-based offence need not be unreasonable. One can imagine individuals who do not personally believe that most nudists are perverts, or that naked bodies are ugly for that matter, but who simply find public nudity offensive. Could such visceral offence justify existing anti-nudist laws?

The answer seems negative, as this kind of offence would still be rooted in prejudices about nudism. To see this, it should be noted that there is nothing inherent to the sight of naked bodies that is bound to cause offence, or even merely likely to do so (in this regard, nudism-based offence differs from, say, offence caused by loud grating noises, which induce unpleasant states in people quite independent from their cultural background). Evidence for this claim can be found in the cross-cultural and cross-temporal differences in people's attitudes towards public nudity (Carr-Gomm 2012); the fact that children are not bothered by exposure to public nudity until later stages of their socialisation; and the many contexts in which witnessing naked bodies does not ordinarily cause offence (e.g. in bedrooms, saunas, dressing rooms).Yet if I am right that that the visceral offence that exposure to non-sexual public nudity induces in some can be explained only by reference to the anti-nudist prejudices that permeate their socio-cultural environment, then regardless of whether the offendees believe these prejudices to be true, the tainted origins of their offence renders it an unsuitable ground for restricting people's liberties. To see this, recall those who take offence at interracial couples who hold hands in public. Even when these individuals do not personally believe that there is anything wrong with such behaviour, it would nonetheless be inappropriate to proscribe interracial hand-holding based on their offence, given that the shock, disgust and/or anger they experience seem to be rooted in prejudicial beliefs that suffuse their racist socio-cultural milieu (there certainly is nothing natural about being shocked, disgusted, or angered by interracial displays of affection). Similarly, if my claim that nudism-based offence is rooted in prejudices 
is correct, then the fact that prejudicial beliefs cannot morally justify laws means that current anti-nudist laws cannot be vindicated.

Does this mean that nudism-induced offence is not something that states should ever be concerned with? At least when the offendees cannot be held responsible for their offence, perhaps because they have grown up in a society that is hostile to nudism-I believe the answer is 'no'. Such feelings are problematic and require a political response. However, the proper way to respond to them is not to maintain current restrictions on nudism but to adopt the following two-pronged approach.

First, states should inform their residents about the morally innocent motives of the large majority of nudists. Ways in which they might do this include launching media campaigns and making nudism-education part of the school curriculum. Second, to help people overcome their nudism-induced offence, states should promote non-sexualised outlooks on the naked body. Possible measures are organising workshops that teach individuals how to relate to nudity in a different way and regulating more heavily the use of sexualised nudity in advertising (observe that states have reason to adopt these measures irrespective of whether people are offended by public nudity, given that the sexualisation of contemporary liberal societies contributes to a climate in which women are more likely to suffer sexual abuse and in which asexual individuals are more likely to feel alienated ${ }^{41}$ ). Replacing existing anti-nudist laws with this two-pronged approach does not only serve the interests of nudists by helping to eliminate widespread misconceptions about nudism, but also those of many non-nudists, who might benefit from discovering nudism's potential recreational and spiritual value and/or whose body image might be improved by exposure to non-idealised bodies (see Sect. 2).

\section{Conclusion}

This article has defended a right to be publicly naked. Such a right allows people to be naked in all public areas, including public beaches, streets, squares, and forests, provided this does not pose a health threat (which, it was noted, it rarely does). To vindicate this right, I showed that the freedom to be publicly naked serves pertinent well-being related and expressive interests, and that any offence that nudism might cause does not override, let alone cancel, the reasons for securing this liberty. Furthermore, I argued that alternative ways of securing the freedom to be publicly naked are wanting, whether this done by subsuming this liberty under traditional liberal rights or simply by excluding non-sexual, non-exhibitionist public nudity from existing laws against public indecency, sexual exhibition, and disorderly conduct.

Let me conclude by noting that states are not the only agents with duties to protect nudist liberties. Private individuals also have such duties. Specifically, they have a negative duty to desist from criticising others for engaging in nonexhibitionist, non-sexual naked activities in public, as well as a positive duty to correct those who engage in such criticism when they can do so at reasonable cost.

$\overline{{ }^{41} \text { For testimonies, see http://www.bbc.co.uk/news/magazine-41569900. }}$ 
Fulfilling these duties is important, for it is only when people can practice nudism "without fear of prudish comment" (Warren 1933, p. 172) that all members of society will be able to reap the benefits of a right to be publicly naked.

Acknowledgements Open access funding provided by Max Planck Society. I would like to thank Benjamin Boudou, Irene de Vries, Martijn van den Brink, and Koen Docter for helpful comments, as well as the reviewers.

Open Access This article is distributed under the terms of the Creative Commons Attribution 4.0 International License (http://creativecommons.org/licenses/by/4.0/), which permits unrestricted use, distribution, and reproduction in any medium, provided you give appropriate credit to the original author(s) and the source, provide a link to the Creative Commons license, and indicate if changes were made.

\section{References}

Acun-Kapikiran, N., Ö. Körükçü, and S. Kapikiran. 2014. The Relation of Parental Attitudes to Life Satisfaction and Depression in Early Adolescents: The Mediating Role of Self-Esteem. Educational Sciences: Theory and Practice 14 (4): 1246-1252.

Carr-Gomm, P. 2012. A Brief History of Nakedness (Reprint). London: Reaktion Books.

Feinberg, J. 1988. The Moral Limits of the Criminal Law: Volume 2: Offense to Others. Oxford: Oxford University Press.

Górnicka, B. 2016. Nakedness, Shame, and Embarrassment: A Long-Term Sociological Perspective. Berlin: Springer.

Hörnle, T. 2006. Legal Regulation of Offence. In Incivilities: Regulating Offensive Behaviour, 01st ed, ed. A.V. Hirsch and A. Simester, 133-148. Oxford; Portland, OR: Bloomsbury Publishing plc.

Kostanski, M., and E. Gullone. 1998. Adolescent Body Image Dissatisfaction: Relationships with SelfEsteem, Anxiety, and Depression Controlling for Body Mass. Journal of Child Psychology and Psychiatry and Allied Disciplines 39 (2): 255-262.

Laitinen, A. 2012. Misrecognition, Misrecognition, and Fallibility. Res Publica 18 (1): 25-38.

Lewis, R.J., and L.H. Janda. 1988. The Relationship Between Adult Sexual Adjustment and Childhood Experiences Regarding Exposure to Nudity, Sleeping in the Parental Bed, and parental Attitudes Toward Sexuality. Archives of Sexual Behavior 17 (4): 349-362.

Okami, P., R. Olmstead, P.R. Abramson, and L. Pendleton. 1998. Early Childhood Exposure to Parental Nudity and Scenes of Parental Sexuality ('Primal Scenes'): An 18-Year Longitudinal Study of Outcome. Archives of Sexual Behavior 27 (4): 361-384.

Okami, Paul. 1995. Childhood Exposure To Parental Nudity, Parent-Child Co-Sleeping, and "Primal Scenes": A Review of Clinical Opinion and Empirical Evidence. The Journal of Sex Research 32 (1): 51-63. https://doi.org/10.1080/00224499509551774.

Oleinick, M.S., A.K. Bahn, L. Eisenberg, and A.M. Lilienfeld. 1966. Early Socialization Experiences and Intrafamilial Environment. A Study of Psychiatric Outpatient and Control Group Children. Archives of General Psychiatry 15 (4): 344-353.

Olivardia, R., R. Pope, G. Harrison, I. Borowiecki, J. John, and G. Cohane. 2004. Biceps and Body Image: The Relationship Between Muscularity and Self-Esteem, Depression, and Eating Disorder Symptoms. Psychology of Men \& Masculinity 5 (2): 112-120.

Paradise, A.W., and M.H. Kernis. 2002. Self-esteem and Psychological Well-being: Implications of Fragile Self-esteem. Journal of Social and Clinical Psychology 21 (4): 345-361. https://doi.org/10. $1521 /$ jscp.21.4.345.22598.

Park, H.-J., D.-G. Lee, and N.M. Yang. 2014. Life Satisfaction in Middle-Aged Koreans: Mediating Effects of Domain-Specific Self-Esteem Satisfaction, and Sex Differences. Psychological Reports 115 (1): 213-227. https://doi.org/10.2466/07.10.PR0.115c11z4.

Persak, N. (ed.). 2016. Regulation and Social Control of Incivilities, 1st ed. New York, NY: Routledge. 
Pujols, Y., C.M. Meston, and B.N. Seal. 2010. The Association Between Sexual Satisfaction and Body Image in Women. The Journal of Sexual Medicine 7 (2 Pt 2): 905-916. https://doi.org/10.1111/j. 1743-6109.2009.01604.x.

Raz, J. 1988. The Morality of Freedom. Oxford University Press. Retrieved from http://www. oxfordscholarship.com/view/10.1093/0198248075.001.0001/acprof-9780198248071.

Swami, V. 2016. Illustrating the Body: Cross-Sectional and Prospective Investigations of the Impact of Life Drawing Sessions on Body Image. Psychiatry Research 235: 128-132. https://doi.org/10.1016/ j.psychres.2015.11.034.

Tasioulas, J. 2006. Crimes of Offence. In Incivilities: Regulating Offensive Behaviour, 01st ed, ed. A.V. Hirsch and A. Simester, 149-172. Oxford; Portland, OR: Bloomsbury Publishing plc.

Warren, H.C. 1933. Social Nudism and the Body Taboo. Psychological Review 40 (2): 160-183.

West, K. 2017. Naked and Unashamed: Investigations and Applications of the Effects of Naturist Activities on Body Image, Self-Esteem, and Life Satisfaction. Journal of Happiness Studies. https:// doi.org/10.1007/s10902-017-9846-1. 